\title{
EXPERIMENTALWORKS
}

\section{PREDNISOLONE AND VITAMIN D MODULATE OXIDATIVE METABOLISM AND CELL DEATH PATHWAYS IN BLOOD AND BONE MARROW MONONUCLEAR CELLS}

\author{
I. O. SHYMANSKYY, O. O. LISAKOVSKA, A. O. MAZANOVA, \\ D. O. LABUDZYNSKYI, A. V. KHOMENKO, M. M. VELIKY
}

Palladin Institute of Biochemistry, National Academy of Sciences of Ukraine, Kyiv;
e-mail: ishymansk@inbox.ru

\begin{abstract}
The study was designed to evaluate reactive oxygen species (ROS)/nitric oxide (NO) formation and apoptotic/necrotic cell death elicited by prednisolone in peripheral blood and bone marrow mononuclear cells and to define the efficacy of vitamin $D_{3}$ to counter glucocorticoid $(G C)$-induced changes. It was shown that prednisolone (5 $\mathrm{mg}$ per $\mathrm{kg}$ of female Wistar rat's body weight for 30 days) evoked ROS and NO overproduction by blood mononuclear cells (monocytes and lymphocytes) that correlated with increased cell apoptosis and necrosis. In contrast, prednisolone did not affect ROS/NO levels in bone marrow mononuclear cells that corresponded to lower level of cell death than in the control. Alterations of prooxidant processes revealed in mononuclear cells and associated with GC action were accompanied by vitamin $D_{3}$ deficiency in animals, which was assessed by the decreased level of blood serum 25 -hydroxivitamin $\mathrm{D}_{3}\left(25 \mathrm{OH} \mathrm{D}_{3}\right)$. Vitamin $D_{3}$ administration (100 IU per rat daily for 30 days, concurrently with prednisolone administration) completely restored $25 \mathrm{OHD}_{3}$ content to the control values and significantly reversed ROS and NO formation in blood mononuclear cells, thus leading to decreased apoptosis. In bone marrow, vitamin $D_{3}$ activated ROS/NO production and protein nitration that may play a role in prevention of prednisolone-elicited increase in bone resorption. We conclude that vitamin $D_{3}$ shows a profound protection against $G C$-associated cellular damage through regulating intracellular ROS/NO formation and cell death pathways.
\end{abstract}

Key words: osteoporosis, prednisolone, vitamin $D_{3}$, blood/bone marrow mononuclear cells, reactive oxygen/nitrogen species, nitric oxide, apoptosis, necrosis.

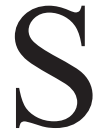
everal adverse effects caused by long-term glucocorticoid (GC) therapy are emerging health problem that limits $\mathrm{GC}$ use for the treatment of patients with various inflammatory and autoimmune diseases, allergies and lymphoproliferative disorders. Osteoporosis is among the most devastating side effects of chronic GC administration associated with significant alterations of mineral metabolism and bone formation [1]. Glucocorticoidinduced osteoporosis causes an increase in bone fractures, delays healing of fractures, and affects the quality of life.

It is known that osteoblasts, together with osteoclasts, control the amount of bone tissue and regulate bone remodeling. The underlying mechanism of osteoporosis is associated with the prevalence of osteoclast-dependent bone resorption over its osteo- blast-mediated formation and mineralization leading to loss of bone mass and mineral density [1]. GCs modify osteoblastic and osteoclastic cell differentiation, number, and function either directly or via influencing the recruitment of their precursors from the bone marrow [2]. Osteoblasts were shown to be originated from bone marrow mesenchymal progenitor cells. Multinucleated osteoclasts are the principle bone resorbing cells that derive from hematopoietic precursors of the monocytic lineage common to peripheral blood monocytes, macrophages and myeloid dendritic cells. Pre-osteoclasts circulate in monocyte fraction of the peripheral blood until they reach the sites of bone resorption.

A common pathologic feature of GC-induced cell disturbances is the development of oxidative stress. Although the effects of prednisolone on cell 
function are largely mediated through glucocorticoid receptors and metabolic changes, recent studies have demonstrated the involvement of reactive oxygen (ROS)/nitrogen species (RNS)-induced modifications of critical cellular macromolecules in modulation of signal transduction cascades and cell death pathways [3]. We have previously described and discussed the pathological role of synthetic glucocorticoid prednisolone in activation of ROS/RNS-mediated hepatocellular death [4]. Currently, insufficient attention was focused on the generation of active metabolites of oxygen and nitrogen in progenitor cells as one of the major determinants contributing to cell dysfunction and abnormalities of bone remodeling.

Alleviating excessive prooxidant reactions might be a promising strategy to prevent or delay the onset of pathological changes induced by GCs. The positive effects of vitamin $\mathrm{D}_{3}$ (cholecalciferol) in maintaining functional activity of different cells may be useful in correcting cellular dysfunction caused by glucocorticoid therapy. Being a ligand for nuclear receptor (VDR), the hormonally active form of vitamin $\mathrm{D}_{3}\left(1,25(\mathrm{OH})_{2} \mathrm{D}_{3}\right)$ regulates the expression of a variety of nuclear genes [5]. The recent discovery of VDR in different cell types has expanded the known function of $1,25(\mathrm{OH})_{2} \mathrm{D}_{3}$ from a role in calcium homeostasis to physiological process of bone formation/resorption and immune cell modulation. Vitamin $\mathrm{D}_{3}$ acting via VDR has been implicated in the mechanisms by which cells proliferate, differentiate, become functionally active or die [6]. Nevertheless, the possible pathogenetic role of impaired vitamin $\mathrm{D}_{3}$ metabolism in the mechanism of GCinduced side effects on bone tissue remodeling still requires better understanding.

Growing evidence suggests that inadequate supply with vitamin $\mathrm{D}_{3}$ is a crucial factor that significantly increases the risk of a number of common pathologies, such as cancer, cardiovascular, infectious, autoimmune and diabetes mellitus [6]. We have recently found that chronic liver injury associated with long-term prednisolone action can be a major cause of vitamin $\mathrm{D}_{3}$ deficiency because liver is known to play a principle role in the synthesis of the prohormone $-25 \mathrm{OHD}_{3}$ [4]. Available scientific data also show that vitamin $\mathrm{D}_{3}$ possesses direct and indirect antioxidant effects in normal and diseased states, effectively inhibiting lipid peroxidation and oxidative damage to proteins in cells of different types, that leads at the structural level to improvement and better preservation of cellular integrity (cell protective effect) and restoration of functional activity of damaged cells [7]. Vitamin $\mathrm{D}_{3}$ is thought to provide anti-inflammatory, immunomodulatory and cytoprotective effects in various tissues [5, 6]. However, there is a lack of consistent information regarding the vitamin $\mathrm{D}_{3}$ ability to prevent ROS/RNS-mediated cell dysfunction associated with the deleterious effects of long-term prednisolone administration in bone marrow.

The present study was therefore aimed at investigating prednisolone-associated modulation of ROS/ nitric oxide (NO) formation and cell death pathways in mononuclear cells from peripheral blood and bone marrow and to evaluate how vitamin $\mathrm{D}_{3}$ administered concurrently with prednisolone attenuates GCinduced disturbances.

\section{Materials and Methods}

Animals. Female Wistar rats weighing $100 \pm 5 \mathrm{~g}$ had unrestricted access to food and water and were housed in temperature and humidity controlled rooms. Animals were randomly divided into 3 groups: 1 - control rats $(n=8) ; 2$ - rats that orally received prednisolone at a dose $5 \mathrm{mg} / \mathrm{kg}$ of body weight (daily for 30 days, $n=8$ ); 3 - rats that orally received prednisolone at a dose $5 \mathrm{mg} / \mathrm{kg}$ of body weight and $100 \mathrm{IU}$ of vitamin $\mathrm{D}_{3}$ (daily for 30 days, $n=8$ ). All animal procedures were performed in accordance with international recommendations of the European Convention for the Protection of Vertebrate Animals used for Research and Scientific Purposes (Strasbourg, 1986), General Ethical Principles of Animal Experimentation, approved by the First National Congress on Bioethics (Kyiv, 2001).

Peripheral blood and bone marrow mononuclear cell isolation. Peripheral blood mononuclear cells were isolated using Histopaque-1083 (Sigma, USA) in accordance with the standard manufacturer's protocol. Bone marrow cells were obtained as briefly described below. Rat femurs were excised, dissected and bone marrow cells were harvested by repeated flushing of the femoral cavities with $1 \mathrm{ml}$ syringe using phosphate-buffered saline (PBS) 10 times. Total marrow isolate was collected by centrifugation at $400 \mathrm{~g}$ for $1 \mathrm{~min}$ at $4{ }^{\circ} \mathrm{C}$ and resuspended in PBS. The resultant cell suspension was filtered through successive 70 and $40 \mu$ m nylon cell strainers followed by washes at $400 \mathrm{~g}$ for $5 \mathrm{~min}$ at $4{ }^{\circ} \mathrm{C}$. Subsequently, red blood cells (RBC) were lysed with RBC Lysis Buffer and the bone marrow mononuclear cells were washed twice, centrifuged and final pellet was resuspended in PBS. 
Serum $25 \mathrm{OHD}_{3}$. Blood was obtained by cardiac puncture for mononuclear cells isolation and analysis of serum 25 -hydroxyvitamin $\mathrm{D}_{3}\left(25 \mathrm{OHD}_{3}\right)$. The content of 25-hydroxyvitamin $\mathrm{D}_{3}$ in serum was assayed using a commercial ELISA kit (The IDS 25-Hydroxy Vitamin D EIA, USA) as described by the manufacturer's protocol.

DCFH oxidation measurement. Fluorescence detection of intracellular reactive oxygen species (ROS) production was analyzed using the fluorogenic probe 2',7'-dichlorodihydrofluorescein diacetate (DCFH-DA; Sigma, USA). ROS generated by cells oxidizes DCFH-DA to produce highly fluorescent green compound $\left(2^{\prime}, 7^{\prime}\right.$-dichlorofluorescein). Isolated cells (approximately $0.5 \cdot 10^{6}$ ) were incubated in Hank's balanced salt solution with DCFHDA concentration of $10 \mu \mathrm{M}$ for $30 \mathrm{~min}\left(37^{\circ} \mathrm{C}\right)$ in a humidified atmosphere of $5 \% \mathrm{CO}_{2}$. Subsequently, the cells were washed, centrifuged, resuspended and fluorescence was measured with an EPICS XLTM flow cytometer (Beckman Coulter, USA) using the excitation/emission wavelengths of $485 / 530 \mathrm{~nm}$. Results were expressed as a relative fluorescence of the samples in comparison to control. Analysis of the results of all studies obtained by flow cytometry was performed using the FCS Express V3 software.

Evaluation of nitric oxide synthesis. Intracellular nitric oxide production in isolated cells was estimated using the specific fluorescent probe 4,5-diaminofluorescein diacetate (DAF-2DA; Sigma, USA). Upon entering the cells, the diacetate bond of the probe is cleaved by intracellular esterases liberating DAF, which specifically reacts with the nitric oxide (II), producing the fluorescent 4,5-diaminofluorescein triazole as an indicator of $\mathrm{NO}$ production in the cell. Immediately after isolation, the cells (approximately $0.5 \cdot 10^{6}$ ) were incubated in Hank's balanced salt solution with dye concentration of $10 \mu \mathrm{M}$ for $30 \mathrm{~min}\left(37^{\circ} \mathrm{C}\right)$ in a humidified atmosphere of $5 \% \mathrm{CO}_{2}$. The fluorescence intensity was measured by EPICS XLTM flow cytometer (Beckman Coulter, USA) using the excitation/emission wavelengths of $495 / 515 \mathrm{~nm}$. Results were normalized to control cells and expressed as a relative fluorescence intensity.

Detection of cell death (apoptosis vs. necrosis assay). Annexin V-EGFP/propidium iodide (PI) double staining was used to differentiate apoptotic vs necrotic cells. In brief, $5 \mu 1$ of Annexin V-EGFP (Abcam, USA) and $5 \mu 1$ of PI (Sigma, USA) $(50 \mu \mathrm{g} / \mathrm{ml})$ were diluted with $500 \mu 1$ of binding buffer and then the mixture was added to the samples $\left(5 \cdot 10^{5}\right.$ bone marrow or blood mononuclear cells). Cells were incubated at room temperature, in the dark, for $15 \mathrm{~min}$ and analyzed by an EPICS XLTM flow cytometer (Beckman Coulter, USA) using the excitation/emission wavelengths of $488 / 530 \mathrm{~nm}$ and $530 / 645 \mathrm{~nm}$, respectively. A minimum of 10,000 cells in gated region was analyzed and results were interpreted by the percentage of total cells appearing in each quadrant.

Western blot analysis of 3-nitrotyrosine. Whole bone marrow cell extracts were prepared as described previously [8]. Bone marrow cells isolated from rats were lysed in RIPA buffer containing protease inhibitor cocktail (PIC, Sigma, USA). Samples of $50 \mu \mathrm{g}$ of protein were loaded on $10 \%$ SDS polyacrylamide gel. After electrophoresis, the proteins were transferred onto nitrocellulose membranes. For protein signal detection, the samples were blocked with a phosphate-buffered saline containing $5 \%$ fatfree milk and $0.05 \%$ Tween- 20 for $1 \mathrm{~h}$ at room temperature. The membrane was than incubated with anti-3-nitrotyrosine antibody (1:4000; Millipore, USA) overnight at $4^{\circ} \mathrm{C}$. After extensive washing, the membrane was incubated with horseradish-peroxidase conjugated anti-mouse secondary antibody at a dilution of $1: 1000$ for $1 \mathrm{~h}$ at room temperature. The bands were visualized by enhanced chemoluminescene agents p-coumaric acid (Sigma, USA) and luminol (AppliChem GmbH, Germany). To provide equal protein loading, membranes were incubated with anti- $\beta$-actin peroxidase conjugated antibody (1:50 000; Sigma, USA) for $1 \mathrm{~h}$. The immunoreactive bands were quantified with Gel-Pro Analyzer 32.

Statistics. Data are expressed as mean \pm SEM for at least six rats per group. Student's $t$-test was used for all analyses and values of $P<0.05$ were considered to indicate statistically significant difference. All calculations were performed using the Microsoft Excel software for $t$-test analysis.

\section{Results and Discussion}

As a close relation exists between vitamin $\mathrm{D}_{3}$ deficiency and increased risk of most deleterious side effects induced by glucocorticoids, we conducted an assessment of 25-hydroxyvitamin $\mathrm{D}_{3}\left(25 \mathrm{OHD}_{3}\right)$ level in blood serum as a reliable biomarker of vitamin $\mathrm{D}_{3}$ bioavailability. Those rats that chronically received prednisolone demonstrated severe vitamin $\mathrm{D}_{3}$ deficiency, since more than 2.5 -fold decrease in $25 \mathrm{OHD}_{3}$ was found in blood serum compared with the control group (Fig. 1). 


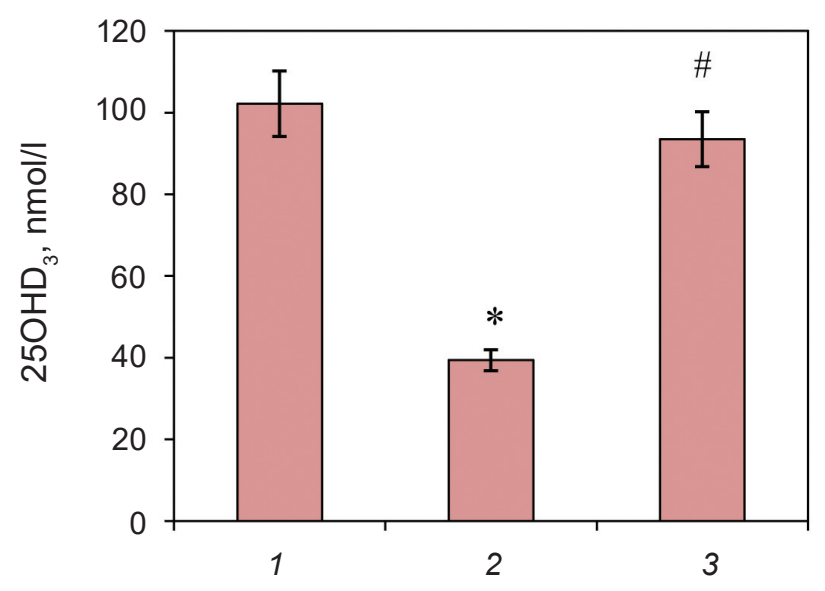

Fig. 1. Effects of prednisolone and vitamin $D_{3}$ administration on 25-hydroxyvitamin $D_{3}$ level in blood serum of three animal groups: 1 - control; 2 - prednisolone administration; 3 - prednisolone and vitamin $D_{3}$ administration. All data are presented as mean \pm SEM $(n=8) ; * P<0.05$ vs. control, ${ }^{\#} P<0.05$ vs. prednisolone administration

These results indicate the negative effect of prednisone on the metabolism of cholecalciferol, which may be linked to significant changes in protein content and activity of vitamin $\mathrm{D}_{3} 25$-hydroxylase isoenzymes in liver cells that we have previously established [9]. Vitamin $\mathrm{D}_{3}$ treatment led to complete restoration of $25 \mathrm{OHD}_{3}$ level. On the background of prednisolone-induced impairment of vitamin $\mathrm{D}_{3}$ metabolism and $\mathrm{D}_{3}$-deficiency significant changes in oxidative metabolism were detected.

Oxidative/nitrosative stress associated with increased generation of reactive oxygen and nitrogen species as well as impaired effectiveness of antioxidant defense has recently been recognized as one of the key mechanisms in the pathogenesis of various disorders associated with $25 \mathrm{OHD}_{3}$ deficiency [10]. To clarify whether alterations of oxidative metabolism are involved in the development of cellular dysfunction associated with GCs, we examined the levels of free radicals formation in mononuclear cells isolated from peripheral blood and bone marrow using DCFH-DA. As DCFH-DA has no specificity in detecting actual oxygen species [11], we use the term ROS as it is generally accepted to encompass the initial species generated by oxygen reduction, as well as their secondary reactive products. DCFH oxidation that reflects the intensity of pro-oxidant processes in cells, are presented in Table 1.

It was found that chronic administration of prednisolone stimulated ROS production in isolated blood mononuclear cells by $35 \%$ compared with the control animals. Vitamin $\mathrm{D}_{3}$ treatment showed antagonistic effect on the level of ROS generation induced by glucocorticoid hormone. In contrast to mononuclear blood cells, the rate of ROS formation in bone marrow cells remained unchanged after prednisolone administration. Despite the fact that prednisolone had no influence on ROS production in bone marrow cells, vitamin $\mathrm{D}_{3}$ treatment slightly increased the level of intracellular oxidants when compared with the control and GC-administered groups.

Cytotoxic and mutagenic effects of ROS/RNS are caused by increased free radical oxidation of physiologically important macromolecules. Moreover, redox modulation of cellular signaling by $\mathrm{NO}$ is central to regulation of cell proliferation, differentiation and death pathways. To assess the potential involvement of nitric oxide and its metabolites in the mechanism of prednisolone-induced changes we next investigated the levels of NO production by isolated cells. It was found using NO-sensitive fluorescent probe, DAF-2DA, that administration of prednisolone results in a significant elevation of $\mathrm{NO}$ synthesis in blood mononuclear cells (by 30\%) as compared with controls (Fig. 2).

Vitamin $\mathrm{D}_{3}$ diminished the level of NO formation in these cells compared with the group of animals administered with the glucocorticoid. Similarly

Ta b le 1. Intracellular ROS production in mononuclear cells isolated from rat bone marrow and peripheral blood after prednisolone and vitamin $D_{3}$ administration, $(M \pm m, n=8)$

\begin{tabular}{l|c|c|c}
\hline \multicolumn{1}{c|}{ Groups } & Control, a.u. & $\begin{array}{c}\text { Prednisolone } \\
\text { administration, } \\
\text { a.u. }\end{array}$ & $\begin{array}{c}\text { Prednisolone } \\
\text { and vitamin } \mathrm{D}_{3} \\
\text { administration, a.u. }\end{array}$ \\
\hline Mononuclear cells from peripheral blood & $452.3 \pm 21.2$ & $668.7 \pm 46.31^{*}$ & $535.1 \pm 23.6^{\#}$ \\
Mononuclear cells from bone marrow & $150.5 \pm 9.9$ & $140.9 \pm 10.4$ & $186.3 \pm 13.7^{\#}$ \\
\hline
\end{tabular}

Note: the ROS levels are shown as mean (fluorescence intensity, a.u. - arbitrary units) \pm SEM; ${ }^{*} P<0.05$ vs. control, \# $P<0.05$ vs. prednisolone administration. 
$A$

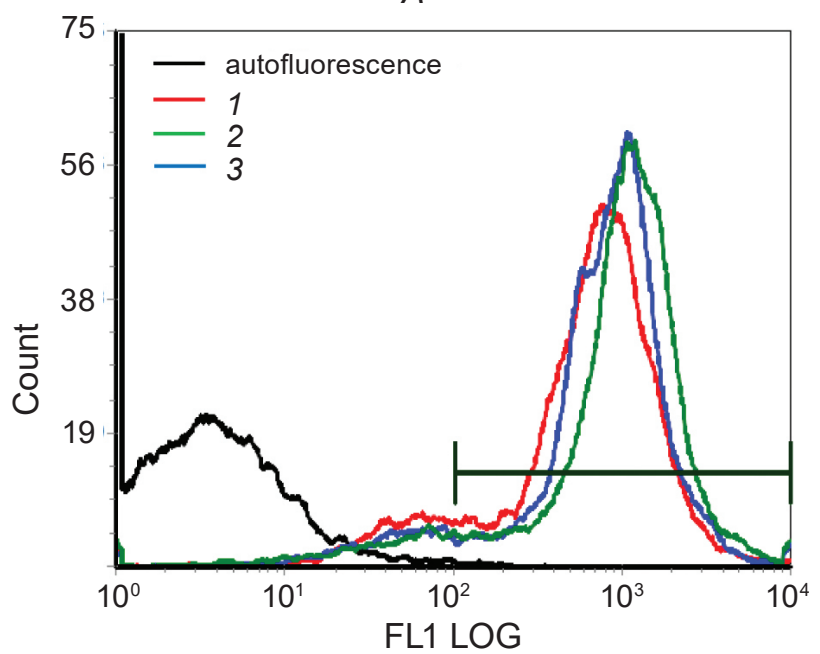

$B$

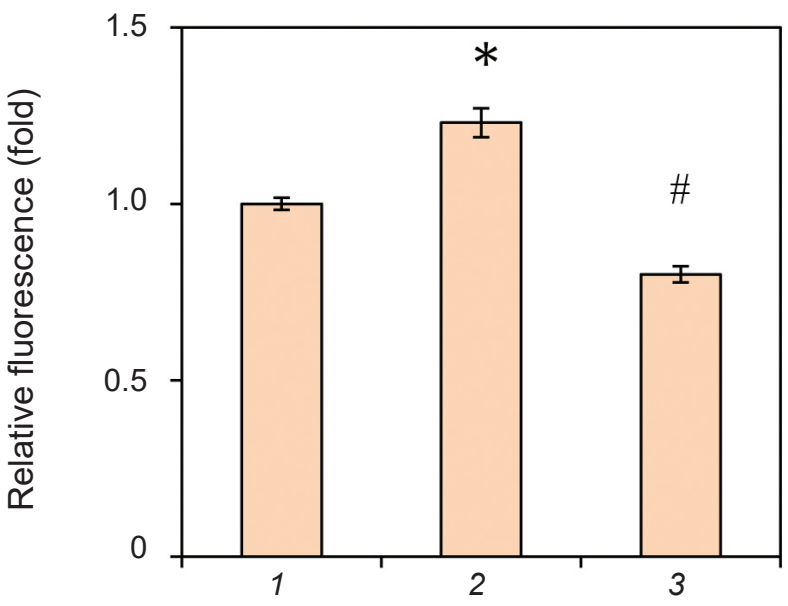

Fig. 2. Effects of prednisolone and vitamin $D_{3}$ administration on nitric oxide formation in rat peripheral blood mononuclear cells. Representative histograms of DAF fluorescence (count - the number of events; FL1 $L O G$ - fluorescence intensity) (A); quantification of DAF oxidation documented by flow cytometry analysis: 1 - control; 2 - prednisolone administration; 3 - prednisolone and vitamin $D_{3}$ administration (B). Results are shown as mean $\pm \operatorname{SEM}(n=8) ; * P<0.05$ vs. control, ${ }^{*} P<0.05$ vs. prednisolone administration

to what we observed in the case of DCFH oxidation, no changes in nitric oxide formation were seen in bone marrow cells in the group of animals that received prednisolone (Fig. 3). Vitamin $\mathrm{D}_{3}$ treatment enhanced NO production to the level almost 2.5 -fold as much as in the control group.

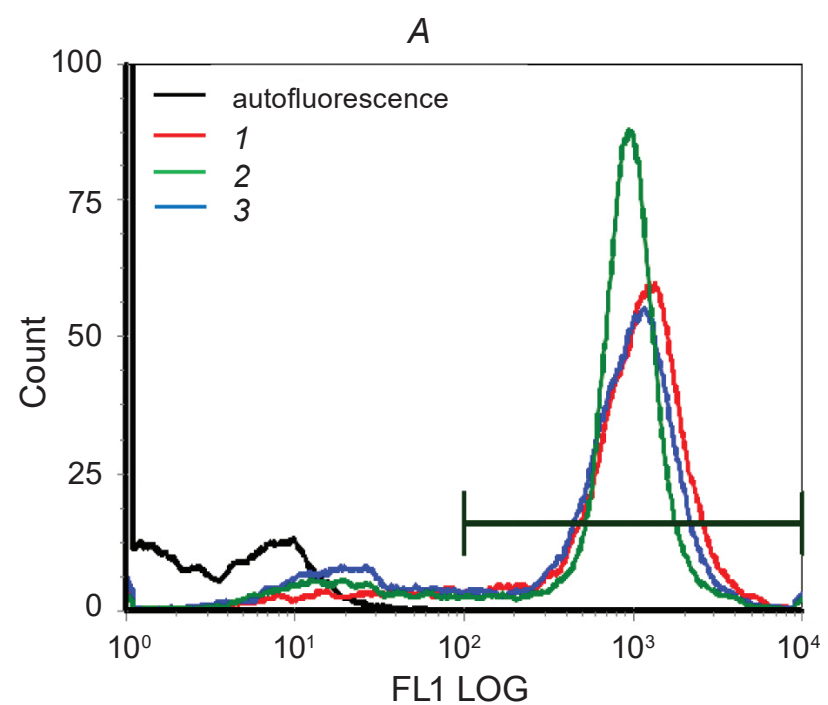

Given that free oxygen and nitrogen species under the conditions of their excess production can mediate either regulatory or cytotoxic effects on cells, it was essential to define whether dependence exists between the intensity of ROS/RNS formation and cell death following prednisolone and vi-

Fig. 3. Effects of prednisolone and vitamin $D_{3}$ administration on nitric oxide formation in mononuclear cells isolated from rat bone marrow. Representative histograms of DAF fluorescence (count-the number of events; FL1 LOG - fluorescence intensity) (A); quantification of DAF oxidation documented by flow cytometry analysis: 1 -control; 2 - prednisolone administration; 3 - prednisolone and vitamin $D_{3}$ administration (B). Results are shown as mean $\pm \operatorname{SEM}(n=8) ;{ }^{*} P<0.05$ vs. control, ${ }^{\#} P<0.05$ vs. prednisolone administration 
tamin $\mathrm{D}_{3}$ administration. Quantitative evaluation of apoptosis and necrosis using Annexin V-EGFP/ PI double staining was analyzed by flow cytometry. As shown in Table 2, the rate of blood mononuclear cells with apoptosis and necrosis raised to 14.70 and $10.52 \%$ of total cells after prednisolone administration compared with 11.50 and $7.91 \%$ in control rats, respectively. Treatment with vitamin $\mathrm{D}_{3}$ prevented prednisolone-induced apoptosis without affecting cell necrosis. Prednisolone provided opposite effect on cell death within the bone marrow as compared with peripheral blood mononuclear cells. Following prednisolone administration, a significant reduction of Annexin $\mathrm{V}_{-} \mathrm{EGFP}^{+}$and $\mathrm{PI}^{+}$cells to 6.87 and $0.95 \%$ from 12.85 and $2.07 \%$ in control was established. Vitamin $\mathrm{D}_{3}$ caused a marked increase in apoptotic cell death compared with prednisolone without influencing the number of necrotic cells.

Apoptosis in rat bone marrow cells after vitamin $\mathrm{D}_{3}$ treatment can potentially be ascribed to excess ROS/RNS production. To further confirm that the occurring cell death correlates with oxidative-nitrosative damage to biomolecules, we measured the level of 3-nitrotyrosine by western blotting (Fig. 4).

It is known that tyrosine residues of proteins are sensitive targets for the active nitrating agent peroxynitrite (ONOO-), which is formed by interaction of nitric oxide with superoxide anion radicals. Therefore, the content of 3-nitrotyrosine is regarded as a specific and reliable marker of nitrosative stress. As Fig. 4 depicts, there was no difference in protein nitration between prednisolone-administered and control groups. Compared with prednisoloneadministered rats, bone marrow cells displayed a 2.3-fold induction of nitrosylated proteins after cholecalciferol treatment that corresponds to the level of ROS and NO production by these cells.

Collectively, our findings indicate the development of essential prednisolone-induced alterations of oxidative metabolism and cell death pathways that can be discussed from two following points of view, namely (1) how discrepancies in the effects of prednisolone and cholecalciferol on ROS/RNS production in blood cells and bone marrow cells can be interpreted; and (2) what the functional consequences of the described disturbances could be for bone formation/resorption.

Revealed alterations of oxidative metabolism elicited by chronic prednisolone administration are clearly consistent with the results of cell dysfunction published previously [3, 12]. Excessive GCsevoked production of ROS and oxidative stress were observed in a variety of cell types [13, 14]. By contrast, recent evidence also suggests a protective role of hormonal therapy against oxidative damage to cells [15]. Discrepancies in glucocorticoid ability to modulate pro-/antioxidant status of cells could be accounted for by different experimental conditions. They include doses and administration routes, experimental models, endogenous versus exogenous GC excess, underlying disease for which GCs were administered; and most importantly, there is increa-

Table 2. Evaluation of apoptotic (Annexin V-EGFP-positive) and necrotic (PI-positive) mononuclear cells isolated from rat bone marrow and peripheral blood after prednisolone and vitamin $D_{3}$ administration, $(M \pm m ; n=8)$

\begin{tabular}{l|c|c|c|c|c|c}
\hline \multirow{2}{*}{ Group } & \multicolumn{2}{|c|}{ Control } & \multicolumn{2}{c|}{ Prednisolone administration } & \multicolumn{2}{c}{$\begin{array}{c}\text { Prednisolone and vitamin } \\
\mathrm{D}_{3} \text { administration }\end{array}$} \\
\cline { 2 - 7 } & $\begin{array}{c}\text { Annexin } \\
\text { V-EGFP }, \%\end{array}$ & $\mathrm{PI}^{+}, \%$ & $\begin{array}{c}\text { Annexin } \\
\text { V-EGFP }, \%\end{array}$ & $\mathrm{PI}^{+}, \%$ & $\begin{array}{c}\text { Annexin } \\
\mathrm{V}^{+} \text {-EGFP }, \%\end{array}$ & $\mathrm{PI}^{+}, \%$ \\
\hline $\begin{array}{l}\text { Blood } \\
\text { mononuclear } \\
\text { cells }\end{array}$ & $11.50 \pm 1.02$ & $7.91 \pm 0.45$ & $14.70 \pm 1.31^{*}$ & $10.52 \pm 0.84^{*}$ & $9.31 \pm 0.61^{\#}$ & $9.24 \pm 0.55$ \\
$\begin{array}{l}\text { Bone marrow } \\
\text { mononuclear } \\
\text { cells }\end{array}$ & $12.85 \pm 1.09$ & $2.07 \pm 0.13$ & $6.87 \pm 0.49^{*}$ & $0.95 \pm 0.06^{*}$ & $8.12 \pm 0.63^{\#}$ & $0.78 \pm 0.04$ \\
\hline
\end{tabular}

Note: Mononuclear cells from bone marrow and peripheral blood were stained by Annexin V-EGFP and PI and analyzed by flow cytometry. Summarized data of all measurements are presented as mean (fluorescence intensity, a.u.) \pm SEM, * $P<0.05$ vs. control, ${ }^{\sharp} P<0.05$ vs. prednisolone administration. 
$A$

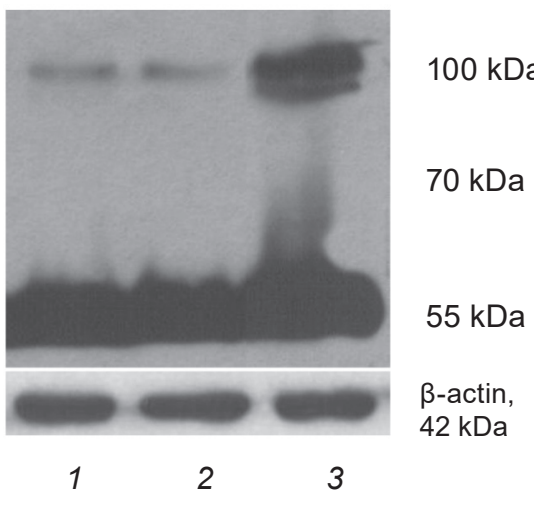

$B$

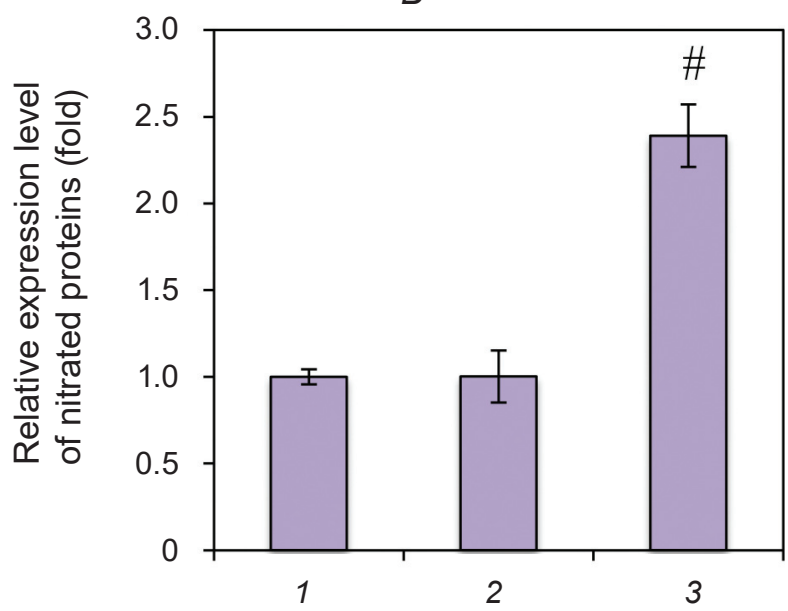

Fig. 4. Effects of prednisolone and vitamin $D_{3}$ administration on the levels of nitrated proteins in bone marrow: 1 -control; 2 - prednisolone administration; 3 - prednisolone and vitamin $D_{3}$ administration. Western blot analysis of total bone marrow lysates was performed using the antibody against 3-nitrotyrosine. Representative immunoblot (A) and quantification of three experiments (B) are shown. The mean protein expression level was quantified as the sum of the densities of immunoreactive bands in each track corresponding to proteins with molecular masses from 50 to $130 \mathrm{kDa}$. Protein levels were normalized to $\beta$-actin. All data are shown as mean $\pm \operatorname{SEM}(n=6) ;{ }^{*} P<0.05$ vs. control, ${ }^{*} P<0.05$ vs. prednisolone administration

sing evidence that early effects may be opposite to effects of prolonged GC action in therapeutically relevant doses.

We can hypothesize that negative impact of chronically administered prednisolone on cellular function may be mediated via impaired interaction of glucocorticoid receptors with prooxidant and/or inflammatory transcription factors to repress transcriptional activity, i.e. transrepression. More recently it has been proposed that transrepression mediates most of the beneficial effects of GCs, whereas transactivation promotes most of their adverse effects [16]. The possible reason for prednisolone-associated cell injury may lie in the inhibitory glucocorticoid action on the expression of factors that not only facilitate ROS/RNS formation but also reduce or limit oxidative stress.

In the present study we followed the prevention paradigm to diminish pathogenic changes caused by chronic administration of prednisolone using concurrent vitamin $\mathrm{D}_{3}$ treatment. Our results have clearly shown the antioxidant effect of vitamin $\mathrm{D}_{3}$ in blood mononuclear cells, while prooxidant action of cholecalciferol on bone marrow progenitor cells was observed. The potent antioxidant activity of vi$\operatorname{tamin} \mathrm{D}_{3}$ has been reported by others $[6,7]$. At the same time several studies also suggest an increase in ROS/RNS production [17]. The dual behavior re- vealed in different tissues shows that the outcome from challenge with an oxidative stress may have relevance to the integration of a series of intracellular signaling mechanisms that depending on cell type involved could both protect against or promote oxidative-nitrosative stress. Modulation of oxidative metabolism by vitamin $\mathrm{D}_{3}$ can largely be mediated by the effects of its hormonally active metabolite 1,25-dihydroxyvitamin $\mathrm{D}_{3}$ through VDR [5]. Overall, vitamin $\mathrm{D}_{3}$ may effectively regulate the rate of free radicals formation in liver cells and their survival via changes of pro/antioxidant and pro/antiapoptotic genes expression [5-7].

Our data may also have significance for understanding a pivotal role of ROS/RNS in osteoblast and osteoclast formation from progenitor marrow cells in the regulation of bone remodeling by steroids. Although glucocorticoids were shown to inhibit bone formation through increasing the death of mature osteoblasts and blocking osteoblastic differentiation from precursor cells, the character of steroid action on osteoclast activity and bone resorption is still a controversial subject. Sustained stimulation of bone matrix degradation by isolated osteoclasts incubated with GCs as well as their cytotoxic effects on osteoclasts have been reported in recent studies [18]. The increase in osteoclast-mediated bone resorption is likely responsible for the initial bone destruction 
after GC administration. In contrast, chronic exposure of high GC doses has inhibiting effects both on bone formation and resorption [19] that largely corresponds to experimental design of the present investigation. Notably, prednisolone-induced pathological changes in bone tissue were confirmed in our previous studies by assessment of bone formation/resorption markers indicative of osteoporosis development.

In spite of the fact that there is still no clear explanation for a direct effect of GCs on osteoclastic precursors, GCs could modulate recruitment of osteoclasts. Our findings may suggest that preosteoclast maturation rather than their formation is impaired in GC-induced osteoporosis. Demonstrated here decreasing effect of prednisolone on apoptosis of bone marrow cells that occurs concomitantly with unchanged rate of ROS/RNS production, most likely reflects the enhancement of bone marrow cells proliferation. As osteoclasts are formed from marrowderived cells that circulate in the monocyte fraction, we also isolated blood mononuclear cells enriched in monocytes to evaluate oxidative metabolism and apoptosis. An increase in oxidative stress and apoptotic death of blood mononuclears suggests a possible prednisolone-induced inhibition of osteoclast differentiation from an early stage of circulating precursor cells. Together, these data are in accordance with a systemic suppression of osteoclast activation by prednisolone that can be related to glucocorticoid influence on early precursors of osteoclasts in the bone marrow and their subsequent differentiation rather than on mature osteoclasts of bone tissue.

It seems quite likely that vitamin $\mathrm{D}_{3}$ can abrogate prednisolone-induced disruptions of key steps in the differentiation and activation of osteoblasts or/and osteoclasts by modulating intracellular redox state as well as survival and death pathways in progenitor cells. Based on the evidence that reactive oxygen species act as signal mediators in cell differentiation, the established ability of vitamin $\mathrm{D}_{3}$ to induce ROS and NO production in bone marrow may suggest additional role for cholecalciferol, beyond its capacity to increase bone mineralization, to promote osteoblast/osteoclast differentiation from hematopoietic precursors. Simultaneous increase in osteoblast and osteoclast formation with subsequent activation of these cells naturally can lead to augmentation of bone turnover that ameliorate prednisolone-evoked loss of bone mass and mineral density. Because of the recent observation that nitric oxide can counter prednisolone-induced osteoporosis [20], induction of NO synthesis in bone marrow cells by cholecalciferol can also be referred to as an important mechanism of osteotropic action of vitamin $\mathrm{D}_{3}$.

In summary, the present study provides support for ROS/RNS and mononuclear cells from blood and bone marrow as therapeutic targets in prednisoloneinduced osteoporosis. It was shown that ROS/nitric oxide production and cell death are differentially regulated by prednisolone depending on cell type. All the alterations associated with GC action were accompanied by vitamin $\mathrm{D}_{3}$ deficient state of animal organism. Vitamin $\mathrm{D}_{3}$ co-administration with prednisolone and restoration of $25 \mathrm{OHD}_{3}$ content may prevent osteoporosis by normalizing impaired oxidative metabolism in mononuclear blood cells and stimulating NO pathway in bone marrow cells. This indicates that vitamin $\mathrm{D}_{3}$ has potential usefulness in the prevention and/or treatment of pathological changes associated with the chronic administration of glucocorticoids.

ПРЕДНІЗОЛОН І ВІТАМІН ${ }_{3}$
МОДУЛЮЮТЬ ОКИСНИЙ
МЕТАБОЛІЗМ І ШЛЯХИ
КЛІТИННОЇ ЗАГИБЕЛІ
МОНОНУКЛЕАРІВ КРОВІ ТА
КІСТКОВОГО МОЗКУ

I. О. Шиманський, О. О. Лісаковська,

А. О. Мазанова, Д. О. Лабудзинський,

А. В. Хоменко, М. М. Великий

Інститут біохімії ім. О.В. Палладіна, НАН України, Київ; e-mail: ishymansk@inbox.ru

Проведено оцінку інтенсивності генерування активних форм кисню (ROS)/оксиду азоту (NO) і шляхів апоптичної/некротичної загибелі мононуклеарів периферичної крові та кісткового мозку за дії преднізолону i встановлено ефективність вітаміну $\mathrm{D}_{3}$ у запобіганні розвитку глюкокортикоїд (GC)-індукованих порушень. Показано, що введення преднізолону (5 мг на 1 кг маси тіла щурів-самиць лінії Wistar протягом 30 днів) зумовлювало надмірне продукування ROS та NO в мононуклеарах крові (моноцити і лімфоцити), що корелювало 3 підвищеними рівнями апоптичної і некротичної загибелі клітин. На противагу цьому, преднізолон не впливав на генерування ROS/NO в монону- 
клеарах кісткового мозку, що приводило до зниження рівня загибелі клітин у порівнянні 3 контролем. Виявлені зміни прооксидантних процесів супроводжувалися розвитком дефіциту вітаміну $\mathrm{D}_{3}$ у тварин, який оцінювали за зниженням концентрації сироваткового $25 \mathrm{OHD}_{3}$. Введення щурам вітаміну $\mathrm{D}_{3}$ (100 MO в день протягом 30 днів одночасно із введенням преднізолону) повністю відновлювало вміст $25 \mathrm{OHD}_{3}$ до рівня контрольних значень та істотно знижувало продукування ROS i NO в клітинах крові, що приводило до зниження їх апоптозу. У клітинах кісткового мозку введення вітаміну $\mathrm{D}_{3}$ спричинювало посилене утворення ROS/NO та нітрування протеїнів, що може відігравати роль у запобіганні індукованої преднізолоном інтенсифікації резорбції кісткової тканини. Таким чином, вітамін $\mathrm{D}_{3}$ ефективно протидіє пошкодженню клітин, асоційованому із тривалим введенням преднізолону, забезпечуючи регуляторний вплив на формування ROS/NO та шляхи клітинної загибелі.

К л ю чо в і с ло ва: остеопороз, преднізолон, вітамін $\mathrm{D}_{3}$, мононуклеари крові/кісткового мозку, активні форми кисню/азоту, оксид азоту, апоптоз, некроз.

\section{ПРЕДНИЗОЛОН И \\ ВИТАМИН D $_{3}$ МОДУЛИРУЮТ \\ ОКИСЛИТЕЛЬНЫЙ МЕТАБОЛИЗМ \\ И ПУТИ КЛЕТОЧНОЙ ГИБЕЛИ МОНОНУКЛЕАРОВ КРОВИ И КОСТНОГО МОЗГА}

\section{И. А. Шиманский, О. А. Лисаковская, \\ А. А. Мазанова, Д. О. Лабудзинский, \\ А. В. Хоменко, Н. Н. Великий}

Институт биохимии им. А. В. Палладина, НАН Украины, Киев; e-mail: ishymansk@inbox.ru

Проведена оценка интенсивности генерации активных форм кислорода (ROS)/оксида азота (NO) и путей апоптической/некротической гибели мононуклеарных клеток периферической крови и костного мозга на фоне введения преднизолона, а также определена эффективность витамина $\mathrm{D}_{3}$ в предотвращении развития глюкокортикоид (GC)-индуцированных изменений. Показано, что преднизолон (5 мг на 1 кг массы тела самок крыс линии Wistar в течение
30 дней) вызывал чрезмерную продукцию ROS и NO в мононуклеарах крови (моноциты и лимфоциты), что коррелировало с повышенными уровнями апоптической и некротической гибели клеток. В противоположность этому, преднизолон не влиял на генерирование ROS/NO в мононуклеарах костного мозга, что приводило к снижению уровня гибели клеток по сравнению с контролем. Выявленные изменения прооксидантных процессов сопровождались развитием дефицита витамина $\mathrm{D}_{3}$ у животных, который оценивали по снижению концентрации сывороточного $25 \mathrm{OHD}_{3}$. Введение крысам витамина $\mathrm{D}_{3}$ (100 MЕ в день в течение 30 дней одновременно с введением преднизолона) полностью восстанавливало содержание $25 \mathrm{OHD}_{3}$ до уровня контрольных значений и значительно снижало выработку ROS и NO в клетках крови, что приводило к снижению апоптоза. В клетках костного мозга введение витамина $\mathrm{D}_{3}$ вызывало усиленное образование ROS/NO и нитрование протеинов, что может играть роль в предотвращении индуцированного преднизолоном повышения резорбции костной ткани. Таким образом, витамин $\mathrm{D}_{3}$ эффективно противодействует повреждению клеток, ассоциированному с продолжительным введением преднизолона, обеспечивая регуляторное воздействие на формирование ROS/NO и пути клеточной гибели.

К л ю че в ы е с ло в а: остеопороз, преднизолон, витамин $\mathrm{D}_{3}$, мононуклеарные клетки крови/костного мозга, активные формы кислорода/ азота, оксид азота, апоптоз, некроз.

\section{References}

1. Hartmann K, Koenen M, Schauer S, WittigBlaich S, Ahmad M, Baschant U, Tuckermann JP. Molecular actions of glucocorticoids in cartilage and bone during health, disease, and steroid therapy. Physiol Rev. 2016; 96(2): 409447.

2. Buehring B, Viswanathan R, Binkley $N$, Busse W. Glucocorticoid-induced osteoporosis: an update on effects and management. $J$ Allergy Clin Immunol. 2013; 132(5): 1019-1030.

3. Lin H, Gao X, Chen G, Sun J, Chu J, Jing K, Li P, Zeng R, Wei B. Indole-3-carbinol as inhibitors of glucocorticoid-induced apoptosis in osteoblastic cells through blocking ROS-mediated Nrf2 pathway. Biochem Biophys Res Commun. 2015; 460(2): 422-427. 
4. Shymanskyy IO, Khomenko AV, Lisakovska OO, Labudzynskyi DO, Apukhovska LI, Veliky MM. The ROS-generating and antioxidant systems in the liver of rats treated with prednisolone and vitamin $\mathrm{D}_{3}$. Ukr Biochem J. 2014; 86(5): 111-125. (In Ukrainian).

5. Saccone D, Asani F, Bornman L. Regulation of the vitamin $\mathrm{D}$ receptor gene by environment, genetics and epigenetics. Gene. 2015; 561(2): 171-180.

6. Basit S. Vitamin D in health and disease: a literature review. Br J Biomed Sci. 2013; 70(4): 161-172.

7. Jain SK, Micinski D. Vitamin D upregulates glutamate cysteine ligase and glutathione reductase, and GSH formation, and decreases ROS and MCP-1 and IL-8 secretion in highglucose exposed U937 monocytes. Biochem Biophys Res Commun. 2013; 437(1): 7-11.

8. Cheng $\mathrm{Q}$, Barboule N, Frit P, Gomez D, Bombarde O, Couderc B, Ren GS, Salles B, Calsou P. Ku counteracts mobilization of PARP1 and MRN in chromatin damaged with DNA double-strand breaks. Nucleic Acids Res. 2011; 39(22): 9605-9619.

9. Khomenko AV. Cholecalciferol hydroxylation in rat hepatocytes under the influence of prednisolone. Ukr Biokhim Zhurn. 2013; 85(3): 90-95. (In Ukrainian).

10. Keeney JT, Förster S, Sultana R, Brewer LD, Latimer CS, Cai J, Klein JB, Porter NM, Butterfield DA. Dietary vitamin D deficiency in rats from middle to old age leads to elevated tyrosine nitration and proteomics changes in levels of key proteins in brain: implications for low vitamin D-dependent age-related cognitive decline. Free Radic Biol Med. 2013; 65: 324-334.

11. Forman HJ, Augusto O, Brigelius-Flohe R, Dennery PA, Kalyanaraman B, Ischiropoulos H, Mann GE, Radi R, Roberts LJ 2nd, Vina J, Davies KJ. Even free radicals should follow some rules: a guide to free radical research terminology and methodology. Free Radic Biol Med. 2015; 78: 233-235.

12 Shymanskyy IO, Lisakovska OO, Mazanova AO, Riasniy VM, Veliky MM. Effects of vitamin $\mathrm{D}_{3}$ and vitamin $\mathrm{E}$ on prednisoloneinduced alterations of phagocyte function. Eur Rev Med Pharmacol Sci. 2016; 20(7): 1379-1383.

13. Shi J, Wang L, Zhang H, Jie Q, Li X, Shi Q, Huang Q, Gao B, Han Y, Guo K, Liu J, Yang L, Luo Z. Glucocorticoids: Dose-related effects on osteoclast formation and function via reactive oxygen species and autophagy. Bone. 2015; 79: 222-232.

14. Omori Y, Mano T, Ohtani T, Sakata Y, Takeda Y, Tamaki S, Tsukamoto Y, Miwa T, Yamamoto K, Komuro I. Glucocorticoids induce cardiac fibrosis via mineralocorticoid receptor in oxidative stress: contribution of elongation factor eleven-nineteen lysine-rich leukemia (ELL). Yonago Acta Med. 2014; 57(3): 109-116.

15. Olteanu D, Filip A, Mureşan A, Nagy A, Tabaran F, Moldovan R, Decea N, Catoi C, Clichici S. The effects of chitosan and low dose dexamethasone on extrahepatic cholestasis after bile duct ligation in Wistar rats. Acta Physiol Hung. 2012; 99(1): 61-73.

16. Stahn C, Buttgereit F. Genomic and nongenomic effects of glucocorticoids. Nat Clin Pract Rheumatol. 2008; 4(10): 525-533.

17. Rizvi A, Farhan M, Naseem I, Hadi SM. Calcitriol-copper interaction leads to non enzymatic, reactive oxygen species mediated DNA breakage and modulation of cellular redox scavengers in hepatocellular carcinoma. Apoptosis. 2016; 21(9): 997-1007.

18. Benvenuti S, Brandi ML. Corticosteroid-induced osteoporosis: pathogenesis and prevention. Clin Exp Rheumatol. 2000; 18(4 Suppl 20): S64-S66.

19. Kim HJ. New understanding of glucocorticoid action in bone cells. BMB Rep. 2010; 43(8): 524529.

20. Pennisi P, D'Alcamo MA, Leonetti C, Clementi A, Cutuli VM, Riccobene S, Parisi N, Fiore CE. Supplementation of L-arginine prevents glucocorticoid-induced reduction of bone growth and bone turnover abnormalities in a growing rat model. J Bone Miner Metab. 2005; 23(2): 134-139. 